\title{
Faktor-Faktor yang Berhubungan dengan Stunted di Kecamatan Ciomas dan Pabuaran Kabupaten Serang
}

\author{
Fitra Salam, ${ }^{1}$ Rizky Suganda Prawiradilaga, ${ }^{2}$ Mirasari Putri ${ }^{2}$ \\ ${ }^{1}$ Program Studi Pendidikan Dokter, \\ ${ }^{2}$ Departemen Biokimia, Gizi, dan Biomolekuler \\ Fakultas Kedokteran, Universitas Islam Bandung
}

\begin{abstract}
Abstrak
Stunted (pendek) merupakan kondisi ketika perbandingan tinggi atau panjang badan dengan usia menunjukkan hasil <-2 standar deviasi berdasar atas WHO Child Growth Standards. Tahun 2018 proporsi anak stunted di Indonesia termasuk kategori prevalensi tinggi dan di Kabupaten Serang untuk tahun 2020 menjadi lokus penurunan permasalahan ini. Banyak faktor yang menjadi faktor risiko stunted, beberapa di antaranya adalah usia ibu saat melahirkan, jenis kelamin anak, usia kelahiran, berat badan lahir, dan penyakit kronis. Tujuan penelitian ini adalah mengetahui faktor-faktor yang berhubungan dengan kejadian stunted. Penelitian dilakukan di wilayah kerja Puskesmas Ciomas dan Pabuaran, Kabupaten Serang, Provinsi Banten periode tahun 2020. Penelitian ini merupakan penelitian observasional analitik dengan desain cross sectional. Jumlah subjek penelitian sebanyak 77 orang yang ditentukan dengan metode purposive sampling. Hasil penelitian menunjukkan hubungan signifikan dengan korelasi rendah pada faktor usia ibu saat melahirkan $(\mathrm{p}=0,049 ; \mathrm{r}=0,2)$, sedangkan pada faktor jenis kelamin anak $(\mathrm{p}=0,990)$, usia kelahiran $(\mathrm{p}=0,997)$, berat badan lahir $(\mathrm{p}=0,549)$, dan riwayat penyakit kronis $(\mathrm{p}=0,648)$ tidak memiliki hubungan signifikan dengan kejadian stunted. Faktor risiko stunted terbagi menjadi beberapa kelompok, yaitu kelompok karakterisitik anak, anggota keluarga, rumah tangga, layanan perawatan kesehatan, dan lingkungan. Usia ibu saat melahirkan merupakan salah satu faktor risiko dari kelompok karakteristik anggota keluarga.
\end{abstract}

Kata kunci: Faktor risiko, gangguan pertumbuhan, stunting, usia ibu

\section{Factors Associated with Stunted in Ciomas and Pabuaran Districts Serang Regency}

\begin{abstract}
Stunted (short) is when the ratio of height or length to age shows a result <-2 standard deviation based on the WHO Child Growth Standards. In 2018 the proportion of stunted children in Indonesia was in the high prevalence category, and Serang Regency for 2020 is the locus for reducing this problem. Many factors are risk factors for stunted, some of which are the mother's age at birth, the sex of the child, the age at birth, birth weight, and chronic disease. This study aimed to determine the relationship between maternal age at delivery and the incidence of stunted. The research was conducted in Puskesmas Ciomas and Pabuaran, Serang Regency, Banten Province, in period 2020. This study was an observational analytic study with a cross-sectional design. The number of research subjects was 77 people who were determined by the purposive sampling method. The results showed that there was a significant relationship with a low correlation between maternal age at childbirth $(p=0.049, r=0.2)$, while for child sex $(\mathrm{p}=0.990)$, birth age $(\mathrm{p}=0.997)$, birth weight $(\mathrm{p}=0549)$, and a history of chronic disease $(\mathrm{p}=0.648)$ had no significant association with the incidence of stunted. Stunted risk factors are divided into several groups, namely groups of characteristics of children, family members, households, health care services, and the environment. Maternal age at delivery is one of the risk factors for the characteristic group of family members.
\end{abstract}

Keywords: Growth disorders, maternal age, risk factor, stunting

Received: 8 ...; Revised: ...; Accepted: ...; Published: ...

Koresponden: Nur Maulida Najwa Rahima. Program Studi Pendidikan Dokter, Fakultas Kedokteran, Universitas Islam Bandung, Jl. Hariangbanga No.2 Email: munajatintan@gmail.com 


\section{Pendahuluan}

Di tahun 2010 diperkirakan 171 juta anak di dunia menderita stunted dengan 167 juta terjadi di negaranegara berkembang. Secara umum, terjadi penurunan prevalensi stunting dari $37.9 \%$ di tahun 1990 menjadi 26.7\% di tahun 2010. Tren ini diperkirakan akan terus berlanjut hingga di tahun 2020 prevalensinya mencapai 21.8\%. ${ }^{1}$ Di Indonesia proporsi stunted (pendek) pada balita di tahun 2018 mencapai angka $30.8 \%$, termasuk di dalamnya $19.3 \%$ pendek $(\mathrm{TB} / \mathrm{U}$ $\geq-3 \mathrm{SD}$ s/d <-2SD) dan $11.5 \%$ sangat pendek $(\mathrm{TB} / \mathrm{U}<-$ 3SD). Di Banten proporsi balita pendek dan sangat pendek sedikit lebih rendah daripada angka rerata nasional. ${ }^{2}$ Angka kejadian stunting di Indonesia meskipun telah mengalami penurunan, namun masih belum memenuhi target yang ditentukan oleh WHO sebesar 20\% dan masih masuk dalam rentang kategori high prevalence yaitu berkisar 30-39\%.3.4 Heni Widhani sebagai Kepala Bidang Kesehatan Masyarakat Dinas Kesehatan Kabupaten Serang mengatakan bahwa Pemerintah Pusat telah menetapkan Kabupaten Serang sebagai lokus penurunan stunting di tahun 2020.5

Stunting adalah gangguan tumbuh kembang yang dialami anak akibat gizi buruk, infeksi berulang, dan stimulasi psikososial yang tidak memadai. ${ }^{6}$ Kondisi ini diukur melalui tinggi atau panjang badan menurut usia. ${ }^{7}$ Seorang anak disebut stunted jika memiliki perbandingan tinggi atau panjang badan dengan usia yang menunjukkan hasil <-2 standar deviasi berdasarkan WHO Child Growth Standards median. ${ }^{6,8}$ Stunting dapat membawa dampak negatif pada pederitanya. Anak pada usia di bawah lima tahun mengalami perkembangan pada berbagai macam aspek. 9 Kondisi malnutrisi seperti stunting dapat berakibat terhadap terhambatnya perkembangan tersebut. ${ }^{10}$ "Stunting berkontribusi sebanyak $14.5 \%$ sebagai penyebab kematian anak usia dibawah 5 tahun pada negara-negara berkembang. Angka kematian akibat tuberkulosis, sepsis, meningitis, selulitis, dan hepatitis meningkat 3 kali lipat pada anak stunting.

Kondisi ini pun meningkatkan morbiditas dan mortalitas dari penyakit-penyakit kronis seperti hipertensi, diabetes melitus tipe 2, dan penyakit kardiovaskular pada saat dewasa. Semua hal ini berdampak negatif pada kondisi sosial-ekonomi yang dicapai oleh mereka di kemudian hari. ${ }^{11}$

Faktor risiko stunting dapat dibagi menjadi lima kelompok besar, yaitu nutrisi dan infeksi ibu, jarak kelahiran yang pendek dan ibu remaja, nutrisi dan infeksi anak, serta faktor lingkungan. ${ }^{12}$ Faktor risiko stunting juga dapat dikelompokkan berdasarkan karakteristik anak, anggota keluarga, rumah tangga, penyedia layanan kesehatan, dan lingkungan. ${ }^{13} \mathrm{Di}$ antara faktor-faktor tersebut adalah usia ibu saat melahirkan, jenis kelamin anak, usia kelahiran, berat badan lahir, dan penyakit kronis. ${ }^{6,12-14}$ Peneltiain ini bertujuan untuk mengetahui faktor-faktor yang berhubungan dengan kejadian stunted.

\section{Metode}

Penelitian ini merupakan penelitian kuantitatif observasional analitik dengan desain cross sectional yang dilakukan di Kecamatan Ciomas dan Pabuaran, Kabupaten Serang, Provinsi Banten tahun 2020. Subjek penelitian merupakan ibu yang mempunyai anak di bawah usia lima tahun yang memenuhi kriteria inklusi dan tidak memenuhi kriteria eksklusi. Kriteria inklusi adalah ibu yang mempunyai anak di bawah usia lima tahun yang terdata tinggi badannya di Puskesmas Ciomas atau Pabuaran. Kriteria eksklusi adalah ibu dan/atau anak yang usianya tidak diketahui secara pasti dan balita dengan penyakit genetik yang dapat memengaruhi pertumbuhan, seperti down syndrome dan achondroplasia. Subjek penelitian sebanyak 77 orang yang ditetapkan dengan metode purposive sampling. Pengambilan data didahului dengan pemberian inform consent kepada subjek penelitian. Protokol penelitian telah mendapat persetujuan etik dari Komite Etik Penelitian Kesehatan Fakultas Kedokteran Universitas Islam Bandung dengan nomor 015/KEPK-Unisba/X/2020.

Analisis statistik menggunakan uji Chi-Square. Hasil dianggap signifikan jika $p$-value yang didapat $<0,05$. Data ditampilkan dalam bentuk tabel. Software yang digunakan dalam analisis statistik adalah IBM SPSS Statistics version 24 IBM Corp., Armonk, NY, USA.

\section{Hasil}

Gambaran karakteristik penelitian pada anak stunted dan tidak stunted ditampilkan pada tabel 1. Berdasar atas tabel 2 karakteristik yang memiliki hubungan dengan stunted adalah usia ibu saat melahirkan $(\mathrm{p}=0,049)$, sedangkan karakteristik yang lain tidak berhubungan $(\mathrm{p} \geq 0,05)$. Hubungan antara usia ibu saat melahirkan dengan kejadian stunted bersifat positif (koefisien korelasi=0,219). Maknanya jika usia ibu saat melahirkan masuk ke dalam kategori rentan, maka kemungkinan muncul anak stunted akan meningkat. Akan tetapi, hubungan keduanya memiliki tingkat keeratan yang rendah (koefisien korelasi=0,200-0,399).

\section{Tabel 1 Karakteristik Penelitian}

\begin{tabular}{|c|c|c|c|}
\hline \multirow{2}{*}{$\begin{array}{c}\text { Karakteristik } \\
\text { Usia Ibu saat Melahirkan }\end{array}$} & \multicolumn{2}{|c|}{ Stunted } & Total \\
\hline & & & \\
\hline Rentan (<20 atau >35 tahun) & 2 & 13 & 15 \\
\hline Tidak Rentan (20-35 tahun) & 25 & 37 & 62 \\
\hline Jenis Kelamin Anak & & & 77 \\
\hline Laki-laki & 13 & 24 & 37 \\
\hline Perempuan & 14 & 26 & $\begin{array}{l}40 \\
77\end{array}$ \\
\hline Usia Kelahiran & & & \\
\hline Tidak Normal (<37 atau >41 minggu) & 11 & 20 & 31 \\
\hline Normal (37-41 minggu) & 15 & 28 & $\begin{array}{l}43 \\
74\end{array}$ \\
\hline Berat Badan Lahir & & & \\
\hline Tidak Normal $(<2.500$ atau $>4.000 \mathrm{~g})$ & 6 & 8 & 14 \\
\hline Normal (2.500-4.000 g) & 21 & 41 & $\begin{array}{l}62 \\
76\end{array}$ \\
\hline Riwayat Penyakit Kronis & & & \\
\hline Ya ( $\geq 3$ bulan $)$ & 1 & 4 & 5 \\
\hline Tidak (<3 bulan) & 26 & 44 & $\begin{array}{l}70 \\
75\end{array}$ \\
\hline
\end{tabular}


Tabel 2 Analisis Bivariat

\begin{tabular}{|c|c|c|c|c|}
\hline \multirow{2}{*}{ Karakteristik } & \multicolumn{2}{|c|}{ Stunted } & \multirow{2}{*}{ P Value } & \multirow{2}{*}{ Koefisien Korelasi (r) } \\
\hline & $\mathbf{Y a}$ & Tidak & & \\
\hline \multicolumn{5}{|l|}{ Usia Ibu saat Melahirkan } \\
\hline Rentan $(<20$ atau $>35$ tahun $)$ & 2 & 13 & $0,049^{*}$ & $\mathbf{0 , 2}$ \\
\hline Tidak Rentan (20-35 tahun) & 25 & 37 & & \\
\hline \multicolumn{5}{|l|}{ Jenis Kelamin Anak } \\
\hline Laki-laki & 13 & 24 & & \\
\hline Perempuan & 14 & 26 & $0,990^{*}$ & \\
\hline \multicolumn{5}{|l|}{ Usia Kelahiran } \\
\hline Tidak Normal ( $<37$ atau $>41$ minggu) & 11 & 20 & & \\
\hline Normal (37-41 minggu) & 15 & 28 & $0,957^{*}$ & \\
\hline \multicolumn{5}{|l|}{ Berat Badan Lahir } \\
\hline Tidak Normal $(<2.500$ atau $>4.000 \mathrm{~g})$ & 6 & 8 & & \\
\hline Normal $(2.500-4.000 \mathrm{~g})$ & 21 & 41 & $0,549^{* *}$ & \\
\hline \multicolumn{5}{|l|}{ Riwayat Penyakit Kronis } \\
\hline Ya ( $\geq 3$ bulan) & 1 & 4 & & \\
\hline Tidak $(<3$ bulan $)$ & 26 & 44 & $0,648^{*}$ & \\
\hline
\end{tabular}

a $=5 \%$ *Pearson Chi-Square ${ }^{* *}$ Fisher's Exact Test

\section{Pembahasan}

Berdasar atas hasil analisis, usia ibu saat melahirkan memiliki hubungan dengan kejadian stunted dengan tingkat keeratan yang rendah. Hasil ini bertentangan dengan penelitiannya Kusumawarhani, Nurruhyuliawati, dan Garna di Kabupaten Bandung, namun sesuai dengan penelitiannya Manggala dkk yang menunjukkan usia rentan ibu saat melahirkan ( $<20$ tahun atau >35 tahun) memiliki hubungan yang signifikan dengan stunted. ${ }^{15,16}$ Pada ibu yang melahirkan di usia muda aliran nutrisi ke janin saat kehamilan belum optimal. Aliran darah ke uterus dan cervix pun belum berkembang dengan baik. Aliran darah ke organ genitourinary yang belum optimal ini meningkatkan risiko infeksi organ-organ tersebut. Tiga mekanisme itu berhubungan dengan kelahiran premature dan berat badan lahir rendah. ${ }^{17}$ " Pada ibu yang melahirkan di usia lebih tua mekanisme yang terjadi adalah hormon progesteron yang kadarnya semakin berkurang, aliran darah utero-placental yang mengalami penurunan, dan peningkatan risiko infeksi intrauterine ${ }^{18}$ Kelahiran premature dan berat badan lahir rendah berhubungan dengan kejadian stunted. ${ }^{12,13,19-22}$

Hasil analisis statistik pada tabel 2 menunjukkan tidak adanya hubungan yang signifikan antara jenis kelamin anak, usia kelahiran, berat badan lahir, dan riwayat penyakit kronis dengan kejadian stunted. Hasil ini berbanding terbalik dengan penelitian-penelitian terdahulu. ${ }^{6,23-27}$

Jenis kelamin berhubungan dengan kejadian stunted. Anak laki-laki lebih berkemungkinan mengalami stunted daripada anak perempuan. Perbedaan jenis kelamin memengaruhi pola perilaku anak dalam komunitasnya. Anak lakilaki cenderung memiliki aktivitas fisik yang lebih banyak dibandingkan anak perempuan, akibatnya ia harus meproduksi energi yang lebih banyak untuk menunjang pertumbuhannya. ${ }^{23,24}$

Usia kelahiran memengaruhi kejadian stunted. Anak yang lahir prematur lebih berisiko 2-3 kali lipat mengalami stunted dibandingkan anak dengan usia kelahiran normal. ${ }^{25}$ Singkatnya usia kehamilan dan retardasi linear yang terjadi sejak masa kehamilan memungkinkan anak dengan kelahiran prematur mengalami pertumbuhan yang lambat. ${ }^{28}$ Bukan hanya mengalami gangguan pertumbuhan, berdasarkan penelitian di Rwanda anak dengan kelahiran prematur pun mengalami keterhambatan perkembangan. ${ }^{29}$ Pada penelitian terdahulu, berat badan lahir memengaruhi kejadian stunted. Anak dengan berat badan lahir rendah lebih berisiko 1,7 kali lipat mengalami stunted dibandingkan dengan anak dengan berat badan lahir normal. Berat badan lahir rendah berkaitan dengan retardasi pertumbuhan dalam uterus dan kelahiran prematur. Pada enam bulan pertama kehidupan, berat badan lahir berefek pada kejadian stunted, namun setelahnya efek tersebut berkurang. Hal ini mungkin berkaitan dengan ketidakcukupan nutrisi yang terjadi pada anak dengan berat badan lahir rendah. ${ }^{26,27}$

Penyakit kronis dan infeksi yang berulang adalah penyebab stunted pada anak. Hal ini terjadi karena kondisi tersebut mampu menyebabkan terganggunya asupan, absorpsi, dan utilisasi nutrien pada penderitanya. Penyakit infeksi saluran cerna dan saluran pernapasan merupakan contoh penyakit infeksi yang menjadi penyebab stunted. ${ }^{6,30}$ Hubungan ini ironis, karena anak dengan stunted berisiko mengalami infeksi berulang dan berisiko mengalami penyakit metabolik dan kardiovaskular kronis ketika dewasa. ${ }^{31}$ Keterbatasan dalam penelitian ini adalah jumlah subjek penelitian yang meskipun telah melampaui target minimal, masih kurang dari yang ditargetkan (100 subjek penelitian). Hal ini terjadi karena keterbatasan peneliti dalam hal waktu dan kemampuan yang berkaitan dengan kondisi demografis dan geografis wilayah setempat.

\section{Simpulan}

Usia ibu saat melahirkan memiliki hubungan dengan kejadian stunted dengan tingkat keeratan hubungan yang rendah. Faktor lain dalam penelitian ini, yaitu jenis kelamin anak, usia kelahiran, berat badan lahir, dan riwayat penyakit kronis tidak memiliki hubungan yang signifikan dengan kejadian stunted.

\section{Ucapan Terima Kasih}

Peneliti mengucapkan terima kasih sebesar-besarnya 
kepada masyarakat serta Puskesmas di Kecamatan Ciomas dan Pabuaran atas kesediaannya membantu penelitian ini.

\section{Daftar Pustaka}

1. de Onis M, Blössner M, Borghi E. Prevalence and trends of stunting among pre-school children, 1990-2020. Public Health Nutr. Januari 2012;15(1):142-8.

2. Badan Penelitian dan Pengembangan Kesehatan. Hasil utama Riskesdas 2018 [Internet]. Jakarta: Kementerian Kesehatan Republik Indonesia; 2018 [dikutip 26 November 2019]. hlm. 1-88. Tersedia dari: www.depkes.go.id

3. Depkes.go.id: Kerjasama multi sektor untuk menurunkan stunting dan eliminasi TB [Internet]. Kementerian Kesehatan Republik Indonesia. 2018 [dikutip 1 Februari 2020]. Tersedia dari: https:// www.depkes.go.id/article/view/18112300002/ kerjasama-multi-sektor-untuk-menurunkanstunting-dan-eliminasi-tb.html

4. World Health Organization. Nutrition landscape information system ( $\square \square$ NLIS) $\square \square$ country profile indicators: interpretation guide [Internet]. World Health Organization; 2010 [dikutip 5 Januari 2020]. Tersedia dari: https://apps.who. int/iris/handle/10665/44397

5. Kabar Banten. 2020, Kabupaten Serang jadi lokus penurunan stunting [Internet]. Kabar Banten Kritis dan Santun. 2019 [dikutip 1 Februari 2020]. Tersedia dari: https://www.kabarbanten.com/2020-kabupaten-serang-jadi-lokuspenurunan-stunting/

6. Who.int: Stunting in a nutshell [Internet]. WHO. 2015 [dikutip 1 Februari 2020]. Tersedia dari: http://www.who.int/nutrition/ healthygrowthproj_stunted_videos/en/

7. Pusat Data dan Informasi Kementerian Kesehatan RI. Situasi balita pendek (stunting) di Indonesia. 2018;1-56.

8. Menteri Kesehatan RI. Peraturan menteri kesehatan nomor 2 tahun 2020 tentang standar antropometri anak. Kementerian Kesehatan RI; 2020.

9. Kliegman R, Stanton B, St. Geme JW, Schor NF, Behrman RE, Nelson WE. Nelson textbook of pediatrics. 21st edition. Philadelphia, MO: Elsevier; 2020.

10. Oot L, Sethuraman K, Sommerfelt AE. Estimating the impact of two common risk factors for stunting - inadequate dietary diversity and teenage pregnancy: models in PROFILES for country-level advocacy. FANTA/FHI 360. Juni 2018;8.

11. Ahmed T, Hossain MI, Islam M, Ahmed AMS, Afroze F. Protein-energy malnutrition in children. Dalam: Hunter's tropical medicine and emerging infectious diseases [Internet]. 10th edition. Canda: Elsevier; 2020 [dikutip 1 Februari 2020]. hlm. 1034-41. Tersedia dari: https://www.clinicalkey. com/\#!/content/book/3-s2.o-B97803235551280 01435 ? indexOverride $=$ GLOBAL

12. Danaei G, Andrews KG, Sudfeld CR, Fink G, McCoy DC, Peet E, dkk. Risk factors for childhood stunting in 137 developing countries: a comparative risk assessment analysis at global, regional, and country levels. Tumwine JK, editor. PLoS Med. 1 November 2016;13(11):e1002164.

13. Titaley CR, Ariawan I, Hapsari D, Muasyaroh A, Dibley MJ. Determinants of the stunting of children under two years old in Indonesia: a multilevel analysis of the 2013 Indonesia basic health survey. Nutrients. 18 Mei 2019;11(5):1106.

14. Stephensen CB. Burden of infection on growth failure. The Journal of Nutrition. 1 Februari 1999;129(2):534S-8.

15. Kusumawardhani A, Nurruhyuliawati W, Garna H. Hubungan riwayat bayi berat lahir rendah dan jumlah anak dalam keluarga dengan kejadian stunting usia 12-59 bulan di Desa Panyirapan Kabupaten Bandung. Jurnal Integrasi Kesehatan dan Sains. 10 Juni 2020;2(1):81-5.

16. Manggala AK, Kenwa KWM, Kenwa MML, Sakti AAGDPJ, Sawitri AAS. Risk factors of stunting in children aged 24-59 months. PI. 7 Agustus 2018;58(5):205-12.

17. Sharma M, Mishra S. Maternal risk factors and consequences of low birth weight in infants. IOSR Journal of Humanities and Social Science (IOSRJHSS). Agustus 2013;13(4):39-45.

18. Waldenström U, Cnattingius S, Vixner L, Norman M. Advanced maternal age increases the risk of very preterm birth, irrespective of parity: a population-based register study. BJOG: Int J Obstet Gy. Juli 2017;124(8):1235-44.

19. Hafid F, Nasrul N. Faktor risiko stunting pada anak usia 6-23 bulan di Kabupaten Jeneponto. IJHN. 1 Juli 2016;3(1):42-53.

20. Amin NA, Julia M. Faktor sosiodemografi dan tinggi badan orang tua serta hubungannya dengan kejadian stunting pada balita usia 6-23 bulan. IJND. 30 Agustus 2016;2(3):170.

21. Nshimyiryo A, Hedt-Gauthier B, Mutaganzwa C, Kirk CM, Beck K, Ndayisaba A, dkk. Risk factors for stunting among children under five years: a cross-sectional population-based study in Rwanda using the 2015 Demographic and Health Survey. BMC Public Health. 11 Februari 2019;19(1):175.

22. Candra A, Puruhita N, Susanto JC. Risk factors of stunting among 1-2 years old children in Semarang City. Media Medika Indonesiana. 2011;45(3):206-12.

23. Mzumara B, Bwembya P, Halwiindi H, Mugode $\mathrm{R}$, Banda J. Factors associated with stunting among children below five years of age in Zambia: evidence from the 2014 Zambia demographic and health survey. BMC Nutrition. 20 Desember 2018;4(1):51.

24. Sumartini E, Gurnida DA, Fadlyana E, Susiarno H, Rusmil K, Effendi JS. Stunting determinant on toddler age of 12-24 months in Singaparna public health center Tasikmalaya Regency. Global Medical \& Health Communication. 31 Desember 2019;7(3):224-31.

25. Sania A, Spiegelman D, Rich-Edwards J, Hertzmark E, Mwiru RS, Kisenge R, dkk. The contribution of preterm birth and intrauterine growth restriction to childhood undernutrition in Tanzania: Preterm birth, IUGR and undernutrition. Matern Child 
Nutr. Oktober 2015;11(4):618-30.

26. Aryastami NK, Shankar A, Kusumawardani N, Besral B, Jahari AB, Achadi E. Low birth weight was the most dominant predictor associated with stunting among children aged 12-23 months in Indonesia. BMC Nutrition. 7 Februari 2017;3(1):16.

27. Lestari ED, Hasanah F, Nugroho NA. Correlation between non-exclusive breastfeeding and low birth weight to stunting in children. Paediatrica Indonesiana. 8 Juni 2018;58(3):123-7.

28. Anugraheni H, Kartasurya M. Faktor risiko kejadian stunting pada anak usia 12-36 bulan di Kecamatan Pati, Kabupaten Pati. Journal of Nutrition College. 4 Oktober 2012;1:30-7.
29. Ahishakiye A, Abimana MC, Beck K, Miller AC, Betancourt TS, Magge H, dkk. Developmental outcomes of preterm and low birth weight toddlers and term peers in Rwanda. Annals of Global Health. 17 Desember 2019;85(1):147.

30. Stewart CP, Iannotti L, Dewey KG, Michaelsen KF, Onyango AW. Contextualising complementary feeding in a broader framework for stunting prevention: Complementary feeding in stunting prevention. Matern Child Nutr. September 2013;9:27-45.

31. Guerrant RL, DeBoer MD, Moore SR, Scharf RJ, Lima AAM. The impoverished gut-a triple burden of diarrhoea, stunting and chronic disease. Nat Rev Gastroenterol Hepatol. April 2013;10(4):220-9. 